IJOTL-TL, Vol. 2, No. 3, September 2017

p ISSN: 2502 2326; e ISSN: 2502 8278

Http://ijolt1.pusatbahasa.or.id; Email: ijolt1@gmail.com

Center of Language and Culture Studies, Surakarta, Indonesia

Budiharso, Teguh. 2017. Developing Prompts of Argumentative Essay Writing for EFL

College Students. IJOTL TL (2017), 2(3): 227 244. DOI:10.30957/ijoltl.v2n3.531.

\title{
DEVELOPING PROMPTS OF ARGUMENTATIVE ESSAY WRITING FOR EFL COLLEGE STUDENTS
}

\author{
Teguh Budiharso \\ Mulawarman University, Samarinda \\ Email: dr_tgh@yahoo.com
}

\begin{abstract}
Assessment on essay writing varies in product oriented, primary trait scoring system, and process oriented. This study examines how rubric on argumentative essay writing are developed. The findings emphasized that essay writing focused on argumentative essay. Models of essay utilized for TOEFL test are considerably suggested for the topics. In addition, descriptors of the essay elaborated for standard assessment refer to characteristics of a good paragraph outlining: topic sentence and controlling ideas, developing sentences, and concluding sentence; and those for essay writing would emphasize on introductory paragraph whose thesis statement is included in the paragraph, developing paragraphs for details, and concluding paragraph.
\end{abstract}

Keywords: prompt, paragraph, essay, argumentative essay.

DOI:10.30957/ijolt1.v2n3.531.

\section{INTRODUCTION}

This study investigates how writing prompt for essay writing course is developed. Persuasive, expository and argumentative essay prompts are focused in this study relying upon analysis of the essay prompts the EFL teachers have made in the teaching practices. Following the prompt design, scoring rubrics are also discussed.

Review of literature on writing program in college levels has shown variety of focuses dependent upon the university level. Some put writing program very formal and requires students to do writing assignment using international standard. Some outlines writing program for general qualification and most devised in trivialities, neglecting the nature of academic writing and assigning students with writing practices that emphasizes on the grammatical problems.

The web of Times4Writing (2017) that serve tutorial on writing assets writing prompt, also called as essay prompts are learning assignment that direct students to write about a particular topic in a particular way. They are designed to integrate a student imagination and creativity into guided writing practices. According to the Times4Writing (2017) writing needs various skills to develop, and one skill of writing that can be taught fairly quickly is "how to understand a writing prompt". Understanding a writing prompt is not simply a matter of reading the prompt, rather it requires students to analyze the prompt before responding to it. 
IJOTL TL, Vol. 2, No. 3, September 2017

p ISSN: 2502 2326; e ISSN: 2502 8278

Http://ijolt1.pusatbahasa.or.id; Email: ijolt1@gmail.com

Center of Language and Culture Studies, Surakarta, Indonesia

Budiharso, Teguh. 2017. Developing Prompts of Argumentative Essay Writing for EFL

College Students. IJOTL TL (2017), 2(3): 227 244. DOI:10.30957/ijoltl.v2n3.531.

Times4Writing (2017) has listed several functions why a student should pay attention to the prompt prior to developing his/he essay. The analysis should focus on the form, purpose, information, details, how to develop paragraphs, audience, and writing style. Specifically, the following questions are addressed:

- What form of writing does it requires?

- What is the purpose of the prompt?

- What information do I need to complete the task?

- What kind of details or arguments does it suggest and would these points make good paragraphs?

- Who is the audience for the essay?

- How does the audience's expectation affect my writing style?

Studies by Latief (2012) and Budiharso (2013) conclude that the objectives of classroom writing program for English college students in Indonesia are the achievement of two kinds of skill, skill in using linguistic aspects of writing (which include coherence, syntax, grammar, and mechanics) and skill in using various rhetorical aspects (modes) of writing (which include narrative, descriptive, and argumentative). Writing courses accordingly teach both skills and focus on skill in using linguistics aspects and skill in using rhetorical modes of writing.

One of the key stumbling blocks of writing prompt interpretation is figuring out what form of writing is required. For example, is it an expository, narrative, or persuasive prompt? Sometimes prompts explicitly specify the form of writing to be used, or give strong hints with words like "persuade" for the persuasive writing form. Other times, the task of deciphering which form of writing to use is part of the challenge (Times4Writing, 2017). The trick is to recognize the clues given in the prompt. Here are some key words to look for suggested by Times4Writing (2017).

- Expository Essay -how, what, explain, define, analyze, compare/contrast

- Narrative Essay -tell, story, relate, imagine, describe

- Persuasive Essay -convince, persuade, why, opinion, argue

Examples of writing prompts below are adapted from Times4Writing (2018) and Module of Writing from Texas University (2018).

\section{Persuasive Essay Writing Prompts \\ Prompt 1 \\ Writing Situation}

In many households where there are teenagers, there are often arguments over cell phones.

\section{Directions for Writing}

Think about the importance of having a cell phone. Now write to persuade your parents to buy you a cell phone or to allow you to keep the cell phone you already have. 
IJOTL TL, Vol. 2, No. 3, September 2017

p ISSN: 2502 2326; e -ISSN: 2502 8278

Http://ijolt1.pusatbahasa.or.id; Email: ijolt1@gmail.com

Center of Language and Culture Studies, Surakarta, Indonesia

Budiharso, Teguh. 2017. Developing Prompts of Argumentative Essay Writing for EFL

College Students. IJOTL TL (2017), 2(3): 227 244. DOI:10.30957/ijoltl.v2n3.531.

\section{Prompt 2}

Writing Situation

In some schools students wear uniforms.

\section{Directions for Writing}

Before you begin writing, think about what is involved when students are required to wear uniforms to school. Now write to persuade your principal to agree with your view on whether school uniforms should be required.

\section{Expository writing prompt \\ Prompt 1 \\ Writing Situation}

Each year millions of tourists visit the state of Florida.

\section{Directions for Writing}

Before you begin writing, think about why Florida is a good place for vacations. Now write to explain the reasons Florida is a popular place for vacations.

\section{Prompt 2 \\ Writing Situation}

Look at this quotation: "Good things are not cheap, and cheap things are not good."

\section{Directions for Writing}

Before you begin to write, think about the meaning of this quotation. Now write to explain how this quotation may apply to an experience of yours or the experience of someone you know.

In developing writing prompt, scoring rubric is vital to consider. In measuring classroom writing skills, two approaches are applied: direct and indirect measurement. The direct measurement refers to evaluation of actual sample of examinees' writing by one or more judges who have been trained in making judgment about writing skills. Indirect measurement refers to observations of specific kinds of knowledge about writing, such as grammar and sentence structure, which can be measured with objectivetype questions (Breland et al, 1987:1).

Both direct and indirect measurements have their own drawbacks. The direct measurement has been criticized as suffering from low reliability resulting from many sources of errors: (1) each judge's personal errors, (2) errors introduced by the limited sampling of topics on which students can write, (3) errors which the judge made because of the influence of paper length, handwriting quality, and neatness, (4) errors in judgment due to the influence of the judgment given to the immediately preceding papers, and (5) errors caused by interactions among the different sources of errors. The indirect measurement, on the other hand, has been criticized as suffering from low 
IJOTL TL, Vol. 2, No. 3, September 2017

p ISSN: 2502 2326; e ISSN: 2502 8278

Http://ijolt1.pusatbahasa.or.id; Email: ijolt1@gmail.com

Center of Language and Culture Studies, Surakarta, Indonesia

Budiharso, Teguh. 2017. Developing Prompts of Argumentative Essay Writing for EFL

College Students. IJOTL TL (2017), 2(3): 227 244. DOI:10.30957/ijoltl.v2n3.531.

validity: it does not measure an actual sample of the examinees' production of writing (Breland et al 1987).

Writing module (Texas University, 2018) describes writing can be assessed in different modes, analytic scoring, holistic scoring, and primary trait scoring. A piece of writing being evaluated using three different scoring should result in similar "scores," though each focuses on a different facet of L2 writing. In Analytic Scoring, a writing is evaluated based on detailed grades for elements as vocabulary, grammar, composition, or mechanics. Results are based on multiple sub-grades (e.g., 4 out of 5 on vocabulary, plus 3 out of 5 on grammar plus 4 out of 5 on content, etc.). Holistic scoring results in a more general description for categories, but includes the different elements of writing implicitly or explicitly. The result is usually a global grade, such as A, B, C, D, E. If the assessment focuses on a particular aspect of writing, or a specific linguistic form, or the use of a certain semantic group, primary trait scoring allows the instructor and the students to focus their feedback, revisions and attention very specifically (Latief, 1990:52; 2012).

Recently, primary trait system has been used widely for Test of Written English (TWE) for the TOEFL. The purpose of the test is to assess test-takers' ability to substantiate an argument in argumentative writing. The modes of the TWE are of three kinds: argument, persuasion, and extension. Argument paper examines quality of arguments the writer presents to both sides of an issue, and take a position. Persuasion requires writer to agree or disagree with a statement and support his opinion with facts. Extension provides writer several examples that support an argument, choose another example and give reason for the choice (Sharpe, 2000:235-237; Budiharso, 2008). The rating was based on (1) whether the writer took a position on the issue, (2) how many pieces of evidence the writer provided, and (3) whether the writer showed how the evidence substantiated the claim.

The purpose of academic writing is usually to explain or to persuade and serve three characteristics: audience, tone, and purpose. The mode is mainly colored with exposition and argumentation, presenting discourse structure and discourse strategy. The discourse structure indicates the knowledge of how to use language in the essay. The discourse strategy suggests the writing style, the way a writer develops his thoughts in words. Through exposition and argumentation modes, the writer can present a position, belief, or conclusion in a strong, emphatic, and rational way; defends a position against critics; persuades people to take certain actions, or attacks a position or an opposing viewpoint (Latief, 1991:8). Rhetoric in an academic writing is implemented in terms of analysis, description, classification, exemplification, definition, comparison, contrast, analogy, narration, process, cause and effect, induction and deduction. The linguistic features concern with the word choice, thematization, hedging, and sentence complexity (Harjanto, 2014).

An expository or analytical essay is an essay that explains or analyzes a topic. In exposition, the writer provides information about a particular subject, using specific details or examples to discuss the topic. The purpose of an expository essay is to clarify facts, opinions, and ideas. A writer of exposition tries to explain the logical relationships between things that exist or can be proved to have existed. The expository 
IJOTL TL, Vol. 2, No. 3, September 2017

p ISSN: 2502 2326; e -ISSN: 2502 8278

Http://ijolt1.pusatbahasa.or.id; Email: ijolt1@gmail.com

Center of Language and Culture Studies, Surakarta, Indonesia

Budiharso, Teguh. 2017. Developing Prompts of Argumentative Essay Writing for EFL

College Students. IJOTL TL (2017), 2(3): 227 244. DOI:10.30957/ijoltl.v2n3.531.

essay relies on the authority, or ethos, the credibility of the writer. The writer assigns authority, the report, and concentrates on exposing the information. He attempts to answer the question of definition "what is it?". The methods of development in exposition include (1) giving examples, (2) supplying reasons, (3) explaining a process, (4) comparing or contrasting, (5) defining, and (6) dividing and classifying (Langan, 1986:111).

Expositions are based on the part-whole relationship, on similarity and difference, and on the specific-general or less general-more general relationship that depends on similarity and difference. Types of exposition are exemplification, analysis (of entities, classes, processes, and sequences), comparison, and definition.

An argumentative essay is one that attempts to change the reader's mind, to convince the reader to agree with the point of view or opinion of the writer. The purpose of argumentative essay is to convince the reader that the writer's position is the better one. An argumentative essay attempts to be highly persuasive and logical. The argumentative thesis takes a side of an issue; frequently, it proposes a course of action (Smalley and Ruetten, 1982:320).

In an argument the central statement answers the questions why. All formal arguments are based on logic. It focuses on an issue and establishes the controversial nature of the topic. More specifically, argumentation focuses on the rational, logical appeal and emphasizes instruction in deductive and inductive reasoning.

An argumentation may take place into one of three parts: argument, persuasion, and extension (Sharpe, 2000:335-337). In the argumentation, the writer examines an issue and she argues both sides and takes a position. Argument to support the evidence is presented in both sides. In persuasion, the writer states to agree or disagree to the issue being presented, and he supports with his opinion. In the extension, the writer presents an issue supported with several examples, the he chooses another example and gives reasons for the choice.

Hogins and Lillard (1972:186-187) assert that an argumentative essay may be organized into three sections: an introductory section, a middle section, and a final section. An introductory section outlines the general controversy. It shows that the topic can be rationally argued, states the primary issues, judges their relative importance, and explains how the writer has organized the rest of the essay. A middle section presents the primary issues one by one in the most efficient order, summarizing the best argument on each side impartially, and offering descriptive commentary when needed but marking no judgments or evaluation. A final section states and defends a conclusion on the issues and the writer's position on the larger controversy.

In addition, Smalley and Ruetten (1982:323-324) illustrate five characteristics of an argumentative essay. The argumentative essay should introduce and explain the issue or case. The essay should offer reasons and support for those reasons. The essay should refute opposing arguments. If an opponent does have a valid point, concede that point. The conclusion should follow the argument. Basically, there are four steps of organization of argumentative essay: introduction, reasons, refutation, and conclusion. 
IJOTL-TL, Vol. 2, No. 3, September 2017

p ISSN: 2502 2326; e -ISSN: 2502 8278

Http://ijolt1.pusatbahasa.or.id; Email: ijolt1@gmail.com

Center of Language and Culture Studies, Surakarta, Indonesia

Budiharso, Teguh. 2017. Developing Prompts of Argumentative Essay Writing for EFL

College Students. IJOTL TL (2017), 2(3): 227 244. DOI:10.30957/ijoltl.v2n3.531.

The focus of this study is writing prompt for argumentative essay for college level. Corresponding to the above focus, the research questions are formulated as follows:

- How is the writing prompt for the argumentative essay developed?

- What validity evidence is available to support the effectiveness of the prompt?

- What scoring rubric is useful for scoring guide using the writing prompt?

\section{METHODS}

The design of this study is Recursive Reflective Design and Development (R2D2) proposed by Willis (1985). Procedure of research involved three stages: definition, planning and development, and dissemination. Subjects of the study were 3 English lecturers, 5 undergraduate students and 5 master's degree students. In the definition stage, various models of argumentative writing prompts were evaluated and new model on the prompts were devised based on the theories of writing assessment. In the planning and development stage, draft of writing prompts was implemented to test the research subjects and modification based on the results of students' works and interviews were made. Development process of the prompt was based on the anchors from which 10 subjects wrote an essay based on the prompt and evaluation from three English lecturers. Planning and development were done three times, resulting prototype of writing prompt and final version of the prompts. In the last stage, the researcher disseminated the writing prompts for writing tests in 10 classes of undergraduate students and 6 classes of master's degree students. Results of dissemination in this study, however, would not be reported.

\section{RESULTS}

\subsection{Defining Stage}

A writing prompt is a set of statement used as a guide to develop a writing. A writing prompt may take place in one of three models. First, the prompt may be of a series of pictures from which students have to draw ideas and write those ideas in the mode called for. Second, the prompt may describe a situation and the students are required to respond that situation in writing. Third, the prompt can simply give directions of what should be done by the students. A well-designed writing prompt (1) requires a clear and unambiguous task, (2) offers sufficient interest to the writers, (3) requires the same tasks for all the writers, (4) has been reviewed for validation evidence by those experienced in writing assessment and educational measurement, and (5) has been tried out with some sample students and revised accordingly (Latief, 1990:53).

A writing prompt should be developed in line with the mode being assessed. The writing prompts below quoted from Latief (1990) and Sharpe (2000) for TWE are presented to exemplify writing assessment using argumentative modes. 
IJOTL TL, Vol. 2, No. 3, September 2017

p ISSN: 2502 2326; e -ISSN: 2502 8278

Http://ijolt1.pusatbahasa.or.id; Email: ijolt1@gmail.com

Center of Language and Culture Studies, Surakarta, Indonesia

Budiharso, Teguh. 2017. Developing Prompts of Argumentative Essay Writing for EFL

College Students. IJOTL TL (2017), 2(3): 227 244. DOI:10.30957/ijoltl.v2n3.531.

Table 1. Example of Writing Prompt for a Final Test at IKIP Malang

Choose either A or B

\section{FINAL TEST}

A. Write an argumentative essay (maximum number words $=400$ ) in which you attempt to enlist your reader's agreement with one of the following opinions.

1. Big cities are exciting places to visit (to live).

2. The latest fad in popular music is getting out of hand.

3. Students no longer exercise good taste in the clothes they wear to class.

4. The number of high-school graduates choosing college education is alarming.

B. The following titles suggest argumentative papers and permit the inclusion of a brief narrative to support your opinion. In writing about these topics, (maximum number of words $=400$ ) you may wish to draw comparison with former times or other situations.

1. Machines are taking away human initiative.

2. It takes courage to be fair.

3. Ignorance is the cause of most of the evil in this world.

4. Boredom is a national disease.

Writing prompt in Table 2 is exemplified from TWE. The purpose of the test is to develop an essay in terms of argumentation, persuasion, or extension. An argumentative essay is to argue both sides of issue and the writer takes a position. The purpose of persuasion is to agree or disagree with a statement and the writer supports his opinion. The extension essay provides the writer several examples that support an argument and the writer chooses another example then gives reasons for his choice. To give comprehensive models, Table 2 presents four number of test.

Table 2. Sample Essay Prompt from TWE

\section{Test Model 1: Argument}

Some students in the United States work while they are earning their degree in college; others receive support from their families. How should a student's education be supported? Argue both sides of the issue and defend your position.

\section{Test Model 2: Persuasion}

Some people say that the best preparation for life is learning to work with others and be cooperative. Others take the opposite view and say that learning to be competitive is the best preparation. Discuss these positions, using specific examples of both. Tell which one you agree with and explain why.

\section{Test Model 3: Extension}


IJOTL TL, Vol. 2, No. 3, September 2017

p ISSN: 2502 2326; e -ISSN: 2502 8278

Http://ijolt1.pusatbahasa.or.id; Email: ijolt1@gmail.com

Center of Language and Culture Studies, Surakarta, Indonesia

Budiharso, Teguh. 2017. Developing Prompts of Argumentative Essay Writing for EFL

College Students. IJOTL TL (2017), 2(3): 227 244. DOI:10.30957/ijoltl.v2n3.531.

Inventions such as eyeglasses and the sewing machine have had important effects on our lives. Choose another invention that you think is important. Give specific reasons for your choice.

Test Model 4: Argument

Read and think about the following statement:

Teachers should make learning enjoyable and fun for their students. Do you agree or disagree with the statement? Give reasons to support your opinion.

\subsection{Planning and Development Stage}

Procedures of development of the writing prompt under study include: identifying the purpose of test, identifying the construct, devising tasks, developing draft of the prompt, proofreading to the writing teachers, providing a try-out to college students, determining scoring rubric and checklist, and revising for final copy. The tryout took place in State Islamic Institute at Surakarta (IAIN) involving three writing lecturers and seventh semester students of English Department and master's degree in Sebelas Maret University that involved 5 students.

\section{a. Conceptual Definition}

Writing prompt for argumentative essay writing for college students is an instrument to assess writing ability using a five-paragraph argumentative mode. The essay consists of parts that are considered standard in the essay writing: introductory paragraph, developing paragraphs, concluding paragraph, coherence, and unity. The essay also indicates the use of rhetoric and linguistics aspects of writing, each of which is described in the organization, content, grammar use, vocabulary, and mechanics of writing.

\section{b. Operational Definitions}

A five-paragraph argumentative essay under study refers to a paragraph using argumentative mode to show the writer took a position on the issue that consists of one introductory paragraph, three developing paragraphs, and one concluding paragraph, and has a thesis statement in the introductory paragraph, developed in accordance with appropriate rhetoric and linguistics features and has proportional uses on organization, content, grammar use, vocabulary and mechanics.

\section{c. Table of Specification of Writing Prompt}

A table of specification outlining task and construct an argumentative writing prompt is devised for the guides of development. The table of specification indicates general aspects to be assessed in the essay. Topic 1 on problems in writing an essay is designed for argumentative essay; topic 2 writing proposal and topic 3 teaching practices are intentionally allowed to present in argumentative or expository modes to give students alternative of writing techniques. See Table 3. 
IJOTL-TL, Vol. 2, No. 3, September 2017

p ISSN: 2502 2326; e -ISSN: 2502 8278

Http://ijolt1.pusatbahasa.or.id; Email: ijolt1@gmail.com

Center of Language and Culture Studies, Surakarta, Indonesia

Budiharso, Teguh. 2017. Developing Prompts of Argumentative Essay Writing for EFL

College Students. IJOTL TL (2017), 2(3): 227 244. DOI:10.30957/ijoltl.v2n3.531.

Table 3. Table of Specification for Writing Prompt

\begin{tabular}{|c|c|c|c|}
\hline No & Topics & Tasks & Constructs \\
\hline 1 & Problems in writing & Argumentative essay & \multirow{3}{*}{$\begin{array}{l}\text { a. Thesis statement } \\
\text { b. Number of } \\
\text { paragraphs } \\
\text { c. Rhetoric \& linguistic } \\
\text { aspects } \\
\text { d. Supporting details } \\
\text { e. Coherence } \\
\text { f. Unity }\end{array}$} \\
\hline 2 & Proposal writing & $\begin{array}{l}\text { Argumentative or } \\
\text { expository essay }\end{array}$ & \\
\hline 3 & Teaching practices & $\begin{array}{l}\text { Argumentative or } \\
\text { expository }\end{array}$ & \\
\hline
\end{tabular}

\section{d. Validation and Revision}

Findings on the validation procedures are obtained from two kinds of activities: proofreading from writing instructors in IAIN and results of assessing students essay writing using the prompt. The proofreading is conducted to verify the prompt including the task, construct, time allotment, clarity of the language, instruction, and scoring information in the prompt. Proofreading on the checklist appropriateness is also discussed to ask suggestions and revision on the substance.

The review requested from the writing instructors focused on: (1) the wording of the prompt (Do the sentences in the prompt show clearly what kind of response, the mode of discourse, the length of paper, the accuracy of language use), (2) the content required by the prompt (Is the content required understood by the students?, (3) the interest in the prompt (Is the topic interesting and alternative topics are provided?), and (4) the terminology in the prompt (Is the terminology clear enough to understand?).

Assessment on the anchor papers from four English department students sitting in the seventh semester at MUS is useful for three concerns: (1) appropriateness between writing prompt and construct, (2) scoring rubric descriptors, and (3) checklist for assessment guide.

The responses from the writing instructors and students' worksheet are classified into four categories, each of which is used to revise the prompt as seen in the final prompt in this study. The responses are (1) modes of discourse be clarified exactly, suggesting topic 1 is argumentative, and the others are both argumentative and expository, (2) the tasks to be assessed should not only writing activities, resulting topic 1 and topic 2 are on writing essay and topic 3 is teaching practice, (3) scoring guides and scoring scale should depend on primary-trait scoring system, suggesting available rubric for TWE for use, and (4) the proposed checklist is strongly suggested and no revision on the checklist is offered.

\section{e. The Devised Writing Prompt}

The writing prompt in Table 4 below refers to conditions of a well-designed writing prompt suggested by Latief (1990:53). 
IJOTL TL, Vol. 2, No. 3, September 2017

p ISSN: 2502 2326; e ISSN: 2502 8278

Http://ijolt1.pusatbahasa.or.id; Email: ijolt1@gmail.com

Center of Language and Culture Studies, Surakarta, Indonesia

Budiharso, Teguh. 2017. Developing Prompts of Argumentative Essay Writing for EFL

College Students. IJOTL TL (2017), 2(3): 227 244. DOI:10.30957/ijoltl.v2n3.531.

Table 4. Writing Prompt for Expository and Argumentative Essay

\section{WRITING PROMPT FOR THE ENGLISH ESSAY}

\section{Direction}

Write an expository essay or an argumentative essay consisting of 5 paragraphs. Put a suitable title for your essay. You can choose one of the topics below. You have 120 minutes to plan your essay, to write the first draft, and to revise it for the final copy. You may use references, dictionaries, grammar books, or notes.

Your essay will be evaluated in terms of its contents, organization, structure, suitable word choice, and mechanics.

\section{Topics to choose}

1. Problems in Writing an Argumentative Essay for English Students of MUS.

2. Writing an English Thesis Proposal Is Hard.

3. Teaching Practices in English College MUS Is A Hard Job.

Four indicators are provided in the prompt in Table 4: (1) a clear and unambiguous task, (2) sufficient interest to the writers indicated by three offered themes, (3) the same tasks for all the writers, (4) been reviewed for validation evidence by those experienced in writing assessment and educational measurement, and (5) been tried out with some sample students and revised accordingly. The purpose of the writing prompt is to assign students to write an essay with expository or argumentative mode. The prompt in Table 4 includes accordingly direction, aspects to be assessed, and topics to be developed.

\subsection{Scoring Rubric to the Devised Writing Prompt}

The scoring rubric useful to assess the paper refers to five elements that exist in an essay: organization, substance, grammar, vocabulary, and mechanics. The rubric is adopted from scoring system for TWE (Sharpe, 2000) and scale ranges from 1 to 6 indicating: very poor $=1$, poor $=2$, fair $=3$, good $=4$, very good $=5$, excellent $=6$. TWE scoring system is considered appropriate because it covers descriptors that primary trait scoring system is well designed in the rubric. See Table 5.

In addition to the scoring scale that result score, a checklist is also used in this study. The checklist is used to check more thoroughly components of paragraph and essay that should be present. Through this checklist, rhetoric and linguistics aspects of an essay are identified. The checklist consists of four main concerns: strategies of supporting ideas, coherence, text checklist, and essay checklist. In the strategies of supporting ideas two concerns are evaluated: sources of development, and experience to authority, e.g. examples, illustration, figures. In the coherence checklist: global and local coherence strategies are identified, showing crafts in developing appropriate signals in the sentence level, paragraph levels, and the whole text levels. In the text 
IJOTL TL, Vol. 2, No. 3, September 2017

p ISSN: 2502 2326; e -ISSN: 2502 8278

Http://ijolt1.pusatbahasa.or.id; Email: ijolt1@gmail.com

Center of Language and Culture Studies, Surakarta, Indonesia

Budiharso, Teguh. 2017. Developing Prompts of Argumentative Essay Writing for EFL

College Students. IJOTL TL (2017), 2(3): 227 244. DOI:10.30957/ijoltl.v2n3.531.

checklist, concerns are focused on: organization of the essay, paragraph development, and sentences and wording. The essay checklist identifies: essay organization and paragraph organization. See Table 6 for clarification.

Checklist to evaluate the global essay adapted from Oshima \& Huges (1991), Harjanto (1999) and Budiharso (2001) is in the appendix.

Table 5. Scoring Rubric for the Guides of Evaluator

\begin{tabular}{|l|l|}
\hline Score 6 & $\begin{array}{l}\text { Is well organized, addresses the topic, includes example and details, } \\
\text { has few errors in grammar and vocabulary }\end{array}$ \\
\hline Score 5 & $\begin{array}{l}\text { Is well organized, addresses the topic, includes fewer examples and } \\
\text { details, has more errors in grammar and vocabulary }\end{array}$ \\
\hline Score 4 & $\begin{array}{l}\text { Is adequately organized, addresses most of the topic, includes some } \\
\text { examples and details, has errors in grammar and vocabulary that } \\
\text { occasionally confuse meaning }\end{array}$ \\
\hline Score 3 & $\begin{array}{l}\text { Is adequately organized, addresses part of the topic, includes few } \\
\text { example and details, has many errors in grammar and vocabulary that } \\
\text { confuse meaning }\end{array}$ \\
\hline Score 2 & $\begin{array}{l}\text { Is disorganized, does not address the topic, does not include examples } \\
\text { and details, has many errors in grammar and vocabulary that } \\
\text { consistently confuse meaning }\end{array}$ \\
\hline Score 1 & $\begin{array}{l}\text { Is disorganized, does not address the topic, does not include examples } \\
\text { and details, has so many errors in grammar and vocabulary that } \\
\text { meaning is not communicated. }\end{array}$ \\
\hline
\end{tabular}

\section{DISCUSSION}

The development of writing prompt for writing assessment should include scoring rubric relevant to the prompt being devised. The writing prompt should deliberately indicate aspects of writing and characteristics of academic writing. The writing aspects include rhetoric and linguistics aspects. Rhetoric indicates the use of language styles and linguistics aspects show the proper uses of grammar, wording, and mechanic of writing.

The way an essay is developed and essay elements are described in the writing is also important concerns. The development process includes proper strategies in developing a paragraph and an essay as a whole. The paragraph level will deal with topic sentence, supporting sentences, concluding sentence, coherence and unity. In the essay level, the development of the paragraphs is developed into introductory paragraph that has thesis statement and function as the opening, the supporting paragraphs where techniques of supporting details through example, statistics, etc are used, and concluding paragraph where thesis and supporting paragraph should be integrated. In addition, coherence in the sentence level in the paragraph and coherence in the essay level among paragraphs are also identified. 
IJOTL TL, Vol. 2, No. 3, September 2017

p ISSN: 2502 2326; e -ISSN: 2502 8278

Http://ijolt1.pusatbahasa.or.id; Email: ijolt1@gmail.com

Center of Language and Culture Studies, Surakarta, Indonesia

Budiharso, Teguh. 2017. Developing Prompts of Argumentative Essay Writing for EFL

College Students. IJOTL TL (2017), 2(3): 227 244. DOI:10.30957/ijoltl.v2n3.531.

The way paragraph and essay elements are identified should be clearly enough to present in the writing prompt. Construct and task of the writing are clarified in the writing prompt. Therefore, the writing prompt is subject to proofreading process from expert in writing assessment and writing instructors.

More specifically, details of description on the assessment should also receive clarification from experts and students doing the assessment. This way, scoring rubric should be well prepared; one that is most appropriate to the argumentative mode is primary-trait scoring system. The scoring system may adopt from available criteria or modify the available criteria for our own relevant use.

In addition, this study introduces also checklist adopted and adapted from various writing sources to assess qualitatively the writing product. The checklist includes identification on supporting details, paragraph level, essay level, coherence, rhetoric, and linguistics aspects of writing. In reference to study by Latief (1990) this study conforms that writing prompt for writing assessment is subject to try-out. The try-out is useful for three areas: obtaining revision on the task and construct in the prompt, relevant and correct use on rubric scoring, and anchor papers from students' sample. This study also confirms that a well-designed writing prompt should follow a five-step development: clear and unambiguous task, sufficient interest and alternative themes, the same tasks for all the writers, validation evidence, and try-out from sample subject for revision.

\section{CONCLUSION}

This study has successfully developed one version of writing prompt and scoring rubric for an assessment of argumentative essay for college students. The product of development consists of three kinds: writing prompt, scoring rubric, and checklist for qualitative evaluation of argumentative papers. Procedures of development combine various sources of writing process from TWE, college writing course, and assessment process for a non-test instrument. Prior to obtaining final version of the product, the prompt has been actually tried-out to writing instructors and sample subjects at MUS. Discussion on the prompt format, scoring rubric, checklist, and anchor papers has been conducted making the product is more convincing.

\section{REFERENCES}

Arnaudent, M. and Barret M.M. 1981. Paragraph Development: A Guide for Students of English as a Second Language. Rowly, Massachusetts: Prentice Hall, Inc.

Breland et al. 1987. Assessing Writing Skill. New York: College Entrance Examination Board.

Brown, HD. 2004. Language Assessment: Principles and Classroom Practices. London: Longman.

Budiharso, Teguh. 2006. The Rhetoric Features of English and Indonesian Essays Made by EFL Undergraduate Students. TEFLIN Journal, 17(2):54-88.

Budiharso, Teguh. 2008. Contrastive Analysis on Rhetoric and Linguistics Features of Academic Essays. Yogjakarta: Penerbit Cawan Mas. 
IJOTL TL, Vol. 2, No. 3, September 2017

p ISSN: 2502 2326; e -ISSN: 2502 8278

Http://ijolt1.pusatbahasa.or.id; Email: ijolt1@gmail.com

Center of Language and Culture Studies, Surakarta, Indonesia

Budiharso, Teguh. 2017. Developing Prompts of Argumentative Essay Writing for EFL

College Students. IJOTL TL (2017), 2(3): 227 244. DOI:10.30957/ijoltl.v2n3.531.

Budiharso, Teguh. 2013. Writing Prompts for Academic Writing. Pedagogik, 10(1):13-23.

Harjanto, I. 1999. English Academic Writing Features by Indonesian Learners of English. Unpublished Doctoral Dissertation. Malang: IKIP MALANG.

Hartfiel, V.F., Hughey, J.B., Wormuth, D.R. Jacobs, H.L. 1985.

Learning ESL Composition: English Composition Program. London: Newbury House Publishers, Inc.

Jacobs, G.M. 1999. Suggestions on Writing for Publication in Language Learning Journals. TEFLIN Journal, 10(1):1-15.

Jacobs, H, Zinkgraf, S.A, Wormuth, D.R., Hartfiel V.F., and Hughey, J.G. 1981. Testing ESL Composition: A Practical Approach. Rowley, Massachusetts: New House Publishers, Inc.

Latief, M.A. 1990. Assessment of English Writing Skills for Students of English as a Second Language at IKIP MALANG Indonesia. Unpublished Ph.D. Dissertation. Iowa City, Iowa: The University of Iowa.

Latief, M.A. 2012. Assessment of English Writing Skills for Students of English as a Second Language. National Seminar. Malang. State University of Malang, 12 January 2012.

Oshima, A. and Houge, A. 1991. Writing Academic English: A Writing and Sentence Structure Handbook. Second Edition. Cambridge: Addison-Wesley Publishing Company.

Penaflorida, H.A. 1998. Non-Traditional Forms of Assessment and Response to Student Writing: A Step Towards Learner Autonomy. In Renandya, A.w and Jacobs, G,M (Eds.) 1998. Learners and Language Learning, SEAMEO Regional Language Centre: Anthology Series 39.

Raimes, A. 1985. What Unskilled Writers Do as They Write: A Classroom Study of Composing. TESOL QUARTERLY 19(2):229-258.

Richards, JC. 1997. Classroom-Based Evaluation in Second Language Education. Cambridge: Cambridge University Press.

Schultz, LM \& Laine, CM. 1986. A Primary Trait Scoring Grid with Assessment and Instructional Uses. Journal of Teaching Writing, 5(1):77-89.

Scott, Virgina M. 1996. Rethinking Foreign Language Writing. Boston, MA: Heinle \& Heinle.

Sharpe, PJ. 2000. How to Prepare for the TOEFL. Ohio: Ohio State University.

Smalley R. and Ruetten. 1983. Refining Composition Skills: Rhetoric and Grammar for ESL Students. New York: Macmillan Publishing Company.

Sommers, N. 1980. Revision Strategies of Students Writers and Experienced Adult Writers. Journal of College Composition and Communication, 31:378677.

Sweeny, A. 1987. A Full Hearing: English in Academic and Research Settings. Cambridge: Cambridge University Press. 
IJOTL-TL, Vol. 2, No. 3, September 2017

p ISSN: 2502 2326; e ISSN: 2502 8278

Http://ijolt1.pusatbahasa.or.id; Email: ijolt1@gmail.com

Center of Language and Culture Studies, Surakarta, Indonesia

Budiharso, Teguh. 2017. Developing Prompts of Argumentative Essay Writing for EFL College Students. IJOTL TL (2017), 2(3): 227 244. DOI:10.30957/ijoltl.v2n3.531.

Times4Writing. 2017. Understanding Writing Prompt.

https://www.time4writing.com/writing.../understanding-writing. Retrieved on July, 42017.

Times4Writing. 2017. Essay Writing Prompts: Zeroing In On Persuasive and

Expository Skills. Available on https://www.dailyteachingtools.com/essaywriting-prompts.h... Retrieved on July 4, 2017.

White, R. and Arndt, V. 1991. Process Writing. London: Longman.

Wingersky, J, Boerner, Holguin-Balogh. 1992. Writing Paragraphs and Essays:

Integrating Reading, Writing, and Grammar Skills. Belmont, California:

Wadsworth Publishing Company. 
IJOTL-TL, Vol. 2, No. 3, September 2017

p ISSN: 2502 2326; e ISSN: 2502 8278

Http://ijolt1.pusatbahasa.or.id; Email: ijolt1@gmail.com

Center of Language and Culture Studies, Surakarta, Indonesia

Budiharso, Teguh. 2017. Developing Prompts of Argumentative Essay Writing for EFL College Students. IJOTL TL (2017), 2(3): 227 244. DOI:10.30957/ijoltl.v2n3.531.

APENDIX

STRATEGIES OF SUPPORTING IDEAS

(Adapted from Oshima and Hogue, 1991 and Harjanto, 1999)

\begin{tabular}{|l|l|l|}
\hline \multicolumn{1}{|c|}{ Types } & \multicolumn{1}{c|}{ Characteristics } & Check \\
\hline 1. Sources Materials & & \\
a. Synthesis & Combine materials & $\ldots \ldots$. \\
b. Summary & Restate materials & $\ldots \ldots \ldots$ \\
c. Critique & Analyze and rewrite & $\ldots \ldots \ldots$ \\
d. Quotation & Copy & $\ldots \ldots \ldots$ \\
2. Experiences Authority and Source of & Examples & $\ldots \ldots \ldots$ \\
Materials & Illustration & $\ldots \ldots \ldots$ \\
\hline
\end{tabular}

\section{COHERENCE CHECKLIST}

\section{Global Coherence}

Signal for all text structures

1. Title

2. Headings

3. Content advance organizers

4. Structural advance organizers

5. Introduction to the topic

6. Topic sentence for each paragraph

7. Summary statement

\section{Local Coherence}

Main Idea

1. Details

a. Figures and statistics

b. Illustrations

c. Exemplification

d. Quotation
YES

NO

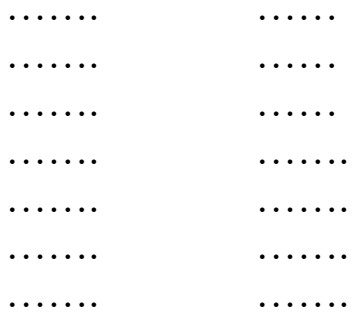

YES

NO

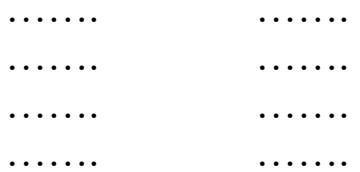

2. Unity

a. Only one main idea in each paragraph

b. Supporting sentences directly relate to main idea

c. Supporting sentence directly explain main idea 


\section{TEXT CHECKLIST \\ (Adopted from Kirszer, L.G and Mandel, S.R., 1978:207-208)}

\section{Organization}

1. Does the essay have:
a. An introduction?
b. A body?
c. A conclusion?
d. A controlling idea?
e. Topic sentences?
f. A restatement of the controlling idea in the conclusion?

\section{The Paragraphs}

1. Does the introduction:
a. Arouse interest?
b. Adequately introduce the subject?
c. Smoothly lead to the controlling idea?

2. Do the body paragraphs:
a. Have topic sentences?
b. Provide focus?
c. Have supporting details?
d. Include adequate transitions?

3. Does the conclusion:
a. Restate the controlling idea?
b. Contain general concluding remarks?
c. Have a final closing statement?

\section{Sentences and Words}

1. Are the sentence patterns correct?
a. Are there sentence fragments?
b. Are there run-on sentences?
c. Are modifiers in the proper places?
d. Are there elements in a series parallel?
e. Are there uncalled-for shifts in subject, voice, number, person, or mood?
f. Are there deadwood and redundancy?
g. Are there sentence pattern variations?
h. Are there overuses of certain words?
i. Are there enough exact words?
j. Are there correct words and expressions?
$\mathrm{k}$. Are there inappropriate shifts in diction levels? 
IJOTL-TL, Vol. 2, No. 3, September 2017

p ISSN: 2502 2326; e ISSN: 2502 8278

Http://ijolt1.pusatbahasa.or.id; Email: ijolt1@gmail.com

Center of Language and Culture Studies, Surakarta, Indonesia

Budiharso, Teguh. 2017. Developing Prompts of Argumentative Essay Writing for EFL

College Students. IJOTL TL (2017), 2(3): 227 244. DOI:10.30957/ijoltl.v2n3.531.

ESSAY CHECKLIST

(Oshima and Hogue, 1991:123)

\section{Essay Organization}

Introduction:

Body:

Conclusion:

\section{Paragraph Organization}

Topic Sentences: Topic sentence for each paragraph: Each topic sentence

Logical and appropriate pattern of organization for the topic (chronological order, logical division, comparisoncontrast, etc.)

Between paragraph transitions

Summary of the main points or paraphrase of the thesis and the final comments on the topic
Supporting

Sentences:

Concluding

Sentence has a controlling idea

Concrete support: Specific

factual details

Unity: Only one main idea in each paragraph

Coherence: Repeating key nouns, using pronouns, transition signals, and logical order

Concluding sentence (if necessary). 
IJOTL TL, Vol. 2, No. 3, September 2017

p ISSN: 2502 2326; e ISSN: 2502 8278

Http://ijolt1.pusatbahasa.or.id; Email: ijolt1@gmail.com

Center of Language and Culture Studies, Surakarta, Indonesia

Budiharso, Teguh. 2017. Developing Prompts of Argumentative Essay Writing for EFL

College Students. IJOTL TL (2017), 2(3): 227 244. DOI:10.30957/ijoltl.v2n3.531. 